\title{
An Experimental Evaluation of the Thermal Performance of Felt Type Vegetated Facade System
}

\author{
Elif Özer Yüksel ${ }^{1}$ and Nil Türkeri ${ }^{2}$ \\ ${ }^{1}$ Department of Architecture, Faculty of Architecture, Gebze Technical University, Kocaeli, Turkey, \\ e.yuksel@gtu.edu.tr \\ ${ }^{2}$ Department of Architecture, Faculty of Architecture, İstanbul Technical University, Kocaeli, Turkey, \\ sahal@itu.edu.tr
}

\begin{abstract}
Vegetated facade systems (VFS) have been used as green building envelope systems in recent years. Using VFS for ecological strategies and evaluating thermal performance of these sytems are not a new concept. However, there is not any experimental study in literature which evaluates thermal performance of felt type VFS applied on an insulated existing building wall which is located in Csa climate during cooling and heating periods. Hence, an experimental study was conducted to measure thermal performance of felt type (type which used felt material as growing media) VFS in Kocaeli (under Csa climate). Test results indicate that in day time with high amount of solar radiation, felt type VFS decreased exterior surface temperatures of an insulated existing wall by maximum of $30^{\circ} \mathrm{C}$. Also, interior surface temperatures of vegetated facade were lower than interior surface temperatures of reference facade with the maxiumum difference of $1.8^{\circ} \mathrm{C}$. Although high differences between exterior surface temperatures of vegetated and reference walls were observed, there was no significant difference between interior surface temperatures of vegetated and reference walls. This is due to the fact that existing building exterior wall assembly includes $5 \mathrm{~cm}$ thickness expanded thermal insulation material which enchance thermal performance of brick wall. In addition, indoor air temperatures behind both facades were close to each other, and were not suitable according to ISO 7730 and ASHRAE 55 Standards comfort range for representative summer days with high ambient air temperatures. Nevertheless, indoor air temperatures behind vegetated facade were in the comfort range in the fall representative day which required cooling, while indoor air temperatures behind reference facade were not in the comfort range in summer representative day.
\end{abstract}

Keywords: Vegetated Facade System, Thermal Performance, Field Measurement, Surface Temperature, Sustainability.

\section{Introduction}

Fourth Assessment Report of Intergovernmental Panel on Climate Change indicates that average temperature on earth has increased by $0.75^{\circ} \mathrm{C}$ from the beginning of the 20th century until today (IPCC, n.d.). Additionally, it is predicted that average air temperature on earth will increase by $1.8-4^{\circ} \mathrm{C}$ at the end of 21 th century (MCCAR, n.d.). Also it is claimed that annual average air temperature in Turkey will rise by $2.5-4^{\circ} \mathrm{C}$ in following years (Turkey's National Climate Change Adaptation Strategy, 2011). Urbanization causes reduction of huge amount of green areas and replaces them with buildings and surfaces with low albedo value (Cheng et al., 2010; Koyama et al., 2013; Wong et al., 2010). These changes cause a significant rise of urban temperature known as heat island effect, which is responsible for the increase of ambient air temperatures (Wong et al., 2010; Alexandri and Jones, 2008). Use of vegetated 
surfaces and vegetated facade systems plays an important role to reduce urban heat island effect (Koyama et al., 2013; Alexandri and Jones, 2008; Olivieri et al., 2014). Greenhouse effect plays also an important role in the increase of ambient air temperatures. Building sector is responsible of $40 \%$ of the $\mathrm{CO}_{2}$ and other greenhouse gases emissions. With improvements in economic development, energy use in building sector has increased (Perez et al., 2017; Technology Roadmap, 2013). In order to decrease greenhouse gases emissions it is essential to use renewable energy sources instead of fossil fuels and/or reduce energy consumptions. Energy consumption caused by building sector can be reduced by several sustainable design strategies. One of them is covering walls with vegetation, that is called as vegetated facade systems (VFS). "Greeney" is a common term in literature, hovewer in the present study it is prefered to nomenclature these systems as "vegetated facade systems" because of the reason that main components of these system are vegetation and growing media. Literature review reveals that vegetated facades minimize heat gain through building facade, decrease surface temperature and increase energy efficiency of buildings (Perez et al., 2017; Safikhani et al., 2014; Raji et al., 2015; Konteleon and Eumorfopoulou, 2010; Haggag et al., 2014; Feng and Hewage, 2014; Perini et al., 2011). Studies in Köppen subgroup "Csa" (mild with no dry and hot summer climate) indicate that vegetated facade systems reduce the maximum exterior surface temperature of reference building surface up to $25^{\circ} \mathrm{C}$ in cooling period (Olivieri et al., 2014; Akbari et al., 1997). Aim of the present paper is to evaluate thermal performance of felt type VFS in Csa climate conditions during cooling period in summer and fall seasons. Also, by means of the results of the present study it is aimed to fill the gap in literature regarding data of thermal performance performance of felt typ measurement parametert results are given and assessed.
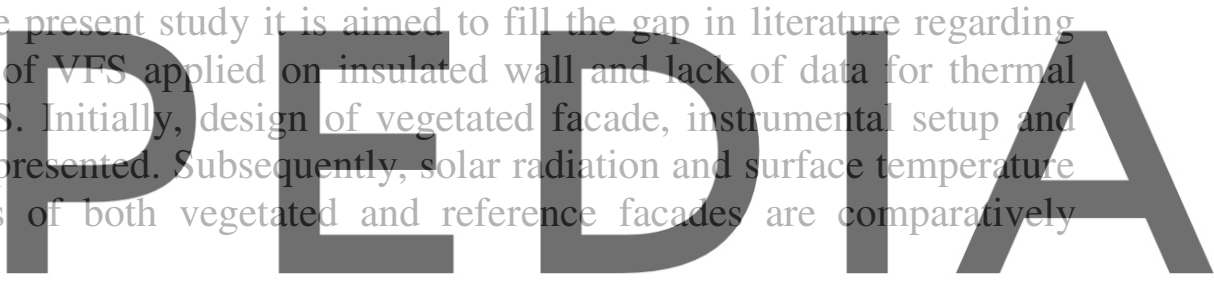

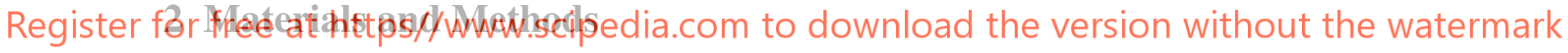

Thermal performance monitoring was conducted at a building located in Gebze Technical University, Gebze, Kocaeii. Gebze Technical University is located at $40^{\circ} 48^{\prime} 41^{\prime \prime} \mathrm{N}, 29^{\circ} 21^{\prime} 19^{\prime \prime} \mathrm{E}$ (GTU, 2017). Kocaeli is classified as "Csa" (mild with dry and hot summer climate) according to Köppen climate classification. Vegetated facade system and instruments were installed in the first week of September 2016. Trial tests were done during 5 months after installation of experimental setup. Monitoring including whole parameters are started on 04 February 2017.

\subsection{Experimental Building}

An existing office building located on Gebze Technical University Campus was chosen as experimental building, two facade surfaces of the building were determined to be used as vegetated and reference facades. Both facades are oriented to the south. They are exposed to solar radiation for the majority of the day (especially hours when solar radiation reaches high values) and there are no obstructions in front of the facades. Also, there is no opening in the respective south oriented walls, both facades are fully opaque and have same dimensions. Window to wall ratio (WWR) of east oriented exterior wall of room which south wall was 
fully vegetated is $20 \%$, while WWR of east oriented exterior wall of room which south wall was non vegetated is $13 \%$. Spaces behind both facades are office rooms which have approximately similar conditions. Both of them have the same heating and cooling systems, which is air conditioning. It operates between 08:00 and 17:00 during week days and doesn't operate during weekends. Existing wall system of the building is composed of the following components from inside to outside: $19 \mathrm{~cm}$ brick wall with $2 \mathrm{~cm}$ thickness interior plaster and $5 \mathrm{~cm}$ thickness expanded polystrene heat insulation material and $3 \mathrm{~cm}$ thickness exterior plaster. This wall system is considered to be reference wall system. Most widely used VFS in Turkey is "felt system" (Yüksel and Türkeri, 2016a). Additionally, there is no previous experimental study in literature in which the thermal performance of a felt type VFS under Csa climate region has been measured during neither cooling period nor heating period (Yüksel and Türkeri, 2016b; Yüksel and Türkeri, 2017). Therefore felt type was chosen as vegetated facade system. Also, "euonymus japonica" was selected due to its well adaptation to survive in temperate and mediterranean climates. The vegetated facade is composed of two main components: existing wall system and vegetated system. Vegetated system consists of following components from inside to outside: 40x40x2mm galvanized steel frame mounted on the wall, PVC panel of $1 \mathrm{~cm}$ thickness fixed on this frame, first and second layers of geotextile felt attached on it and vegetation layer embedded the felt pockets.

\subsection{Instrumental Setup for Monitoring}

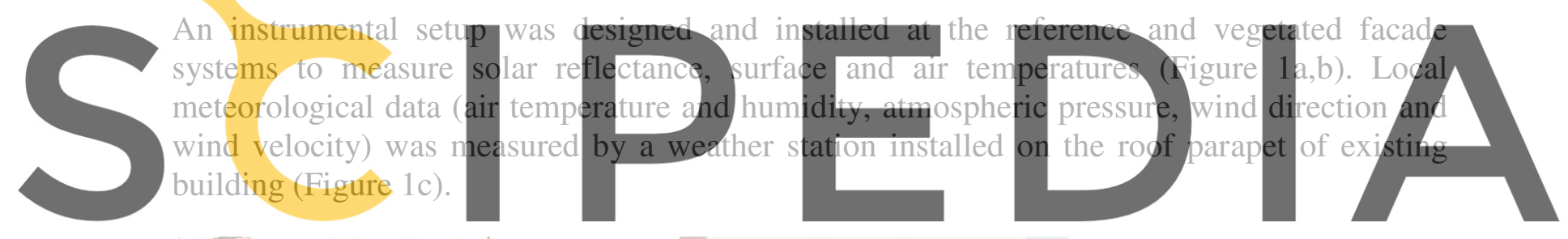

Register for free at https//www.scipedia.com to download the version without the watermark

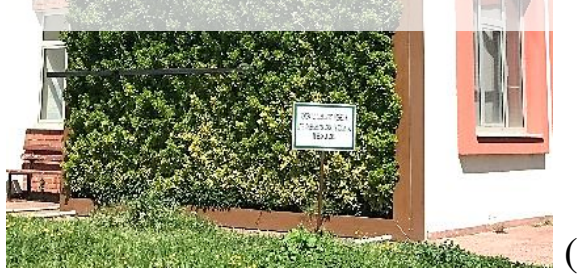

(a)

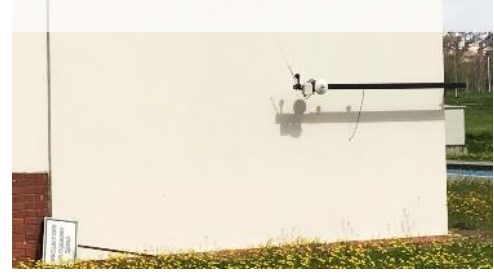

(b)

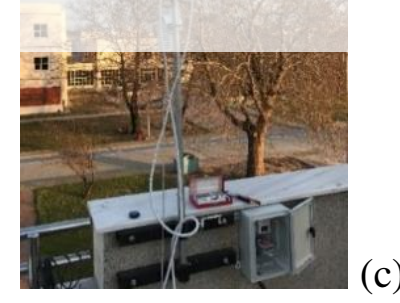

Figure 1. Image of VFS (left) and RFS (middle) and image of the weather station on the roof parapet (right).

Figure 2 designates sections of reference facade and vegetated facade test assemblies. Three pyranometers were used to measure solar radiation incident and solar reflectance. A pyranometer ("I" in Fig. 2b) was installed vertically in front of the vegetated facade to measure solar irradiance reflected from the vegetated facade. Two pyranometers were installed in front of the reference facade vertically and mounted back to back symmetrically. One of these pyranometers, ("D" in Fig. 2a) was used to measure solar radiation incident on reference and vegetated facades and the other ("E" in Fig. 2a) measures solar irradiance reflected from the reference facade. Only one pyranometer was decided to measure incident 
solar radiation since solar radiation values reaching each both facades are accepted as identical. Infrared non-contact thermometers were used to measure surface temperatures of exterior wall of reference facade ("F" in Fig. 2a), exterior wall of vegetated facade ("N" in Fig. 2b), back ("M" in Fig. 2b) and front ("L" in Fig. 2b) side of the PVC panel, second layer of felt ("K" in Fig. 2b). Contact thermometers were used to measure surface temperatures of interior walls of reference ("G" in Fig. 2a) and vegetated ("O" in Fig. 2b) facades. Also, indoor temperature and humidity sensors were placed $20 \mathrm{~cm}$ in front of the interior wall surface of the reference ("H" in Fig. 2a) and vegetated ("P" in Fig. 2b) facades in order the measure indoor air temperature of the rooms behind the vegetated and reference walls. Additionally, a temperature sensor ("J" in Fig. 2b) was placed inside the leaves to measure the air temperature among leaves (Yüksel and Türkeri, 2017).
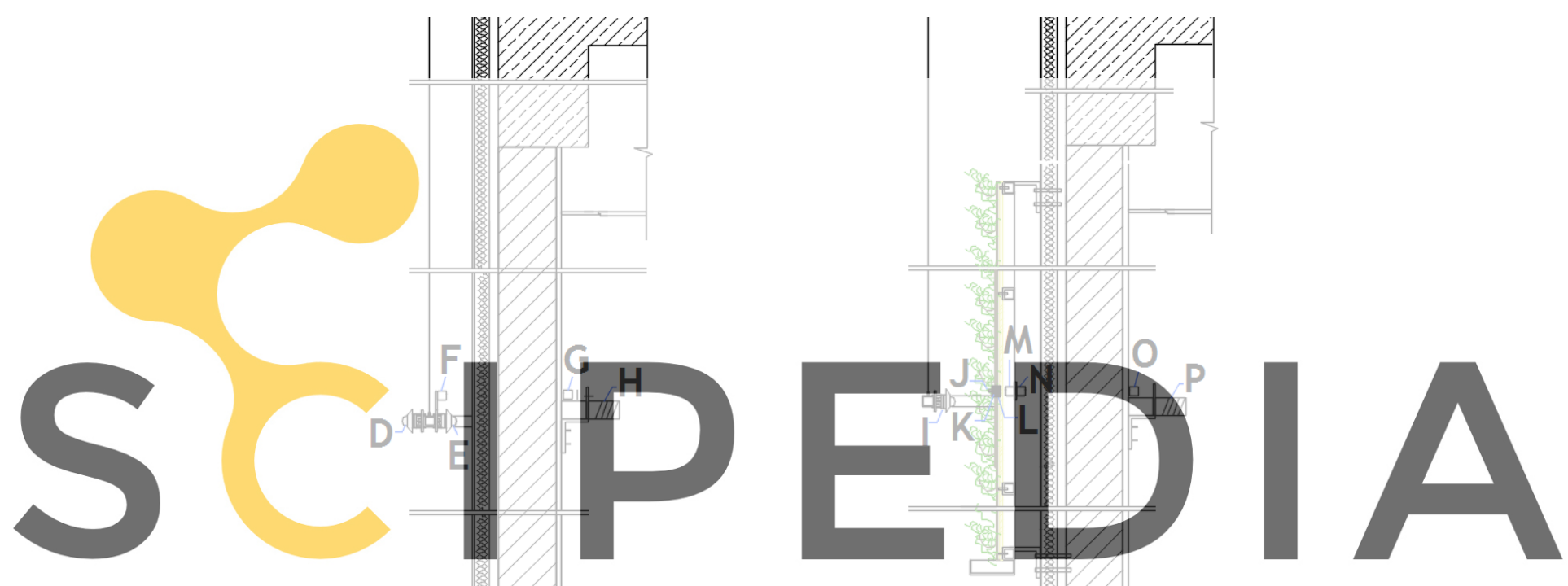

Register for free at https/Awww.scipedia.com to download the version without the watermark

Figure 2. Section of reference facade (left) and vegetated facade (right) test assemblies.

Monitoring periods included months representing summer and fall seasons of the year 2017. Data regarding each parameter was recorded every 10 minutes during these periods. Nevertheless, user behaviours were found to be different in office rooms during weekdays behind vegetated and reference rooms. Hence, representative weekend days were selected for the summer and fall periods when high solar radiation was observed and exterior surface temperatures of reference facade reached maximum values.

\section{Test Results}

Exterior and interior surface temperatures and indoor air temperatures of vegetated and reference facades were compared with each other. Also, indoor air temperatures were evaluated according to comfort temperature range identified in ISO 7730 and ASHRAE 55 Standards. Additionally, solar reflectance ratio of reference facade and vegetated facades were compared with each other. Solar reflectance ratio were calculated according to ASTM E 
1918:2006 (ASTM E1918:2006). For each representative day and for both facades, the ratio of reflected solar irradiance values to total solar irradiance values was calculated between 09:00-15:00. August 12, 2017 and September 24, 2017 were chosen as representative days for the summer and fall periods, respectively, because of the reason that high solar radiation values occured and exterior surface temperatures of reference facade reached maximum values in that hot days. Test results regarding that days such as microclimate values, solar reflectance values of reference and vegetated walls and maximum exterior surface temperatures of reference and vegetated facades are shown in Table 1.

Table 1. Microclimate, solar reflectance and maximum exterior surface temperature values observed on August 12, 2017 and September 24, 2017.

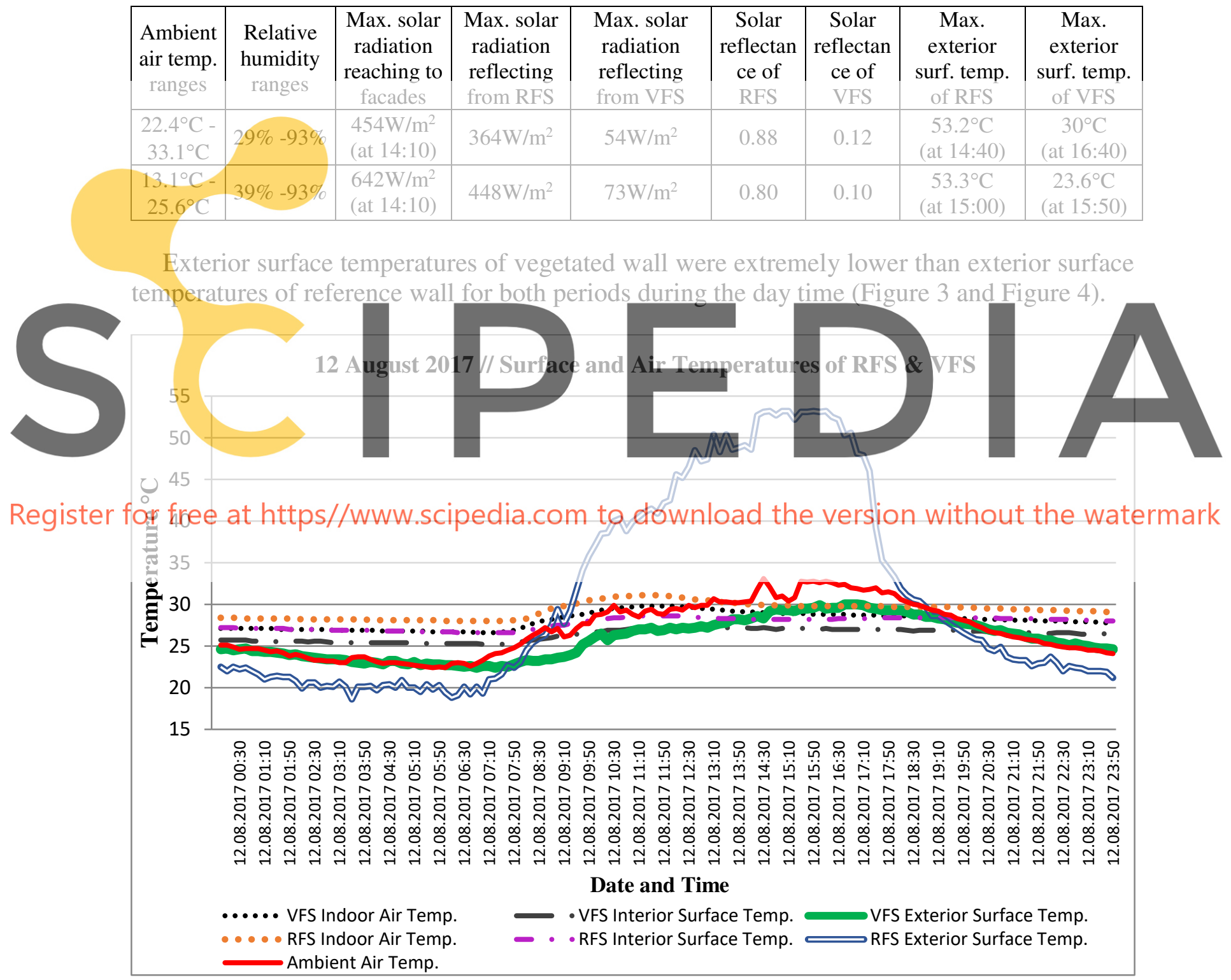

Figure 3. Exterior and interior surface and indoor air temperatures of RFS and VFS on August 12, 2017. 


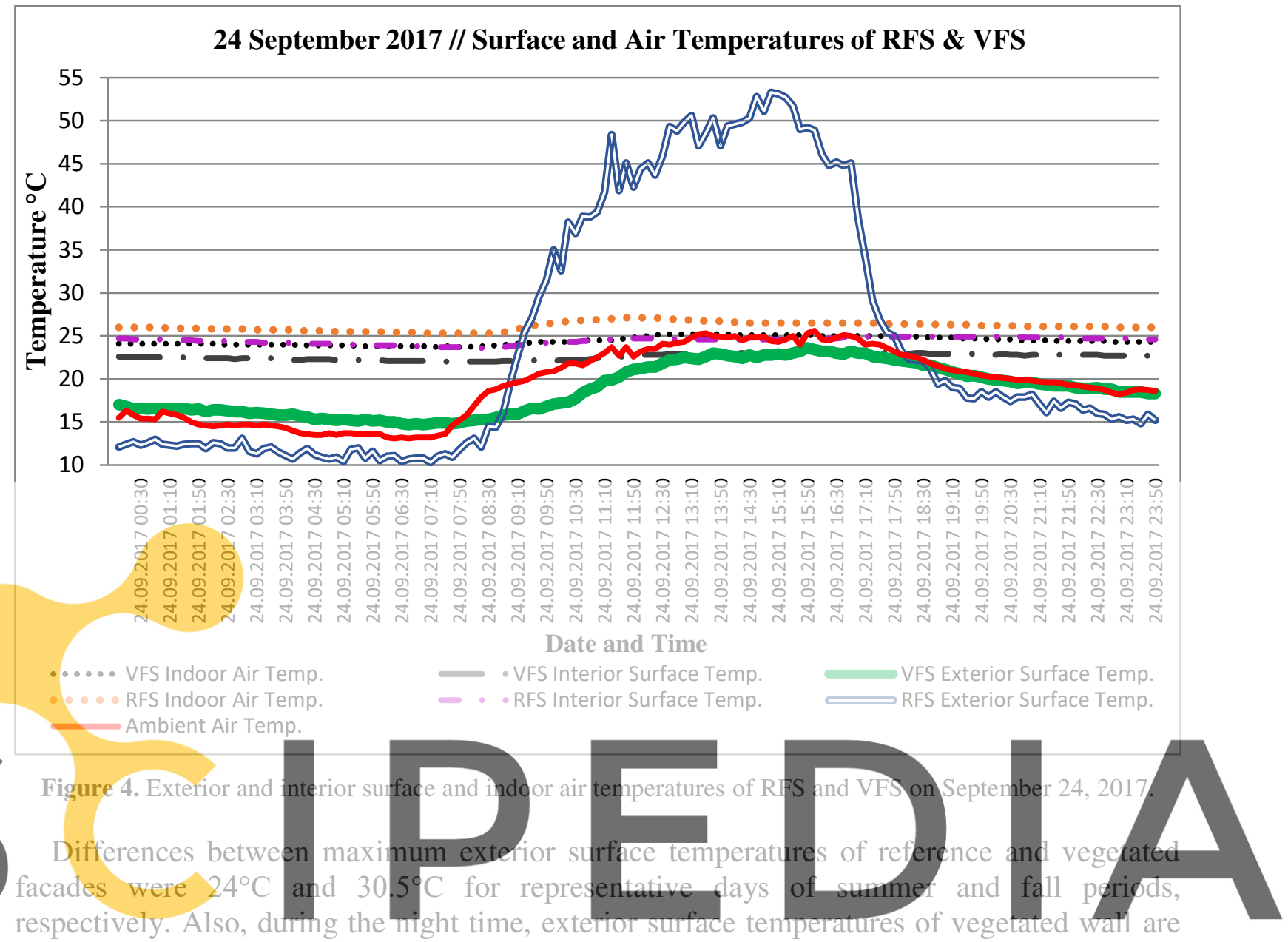

higher than exterior surface temperatures of reference walls for both periods. Interior surface

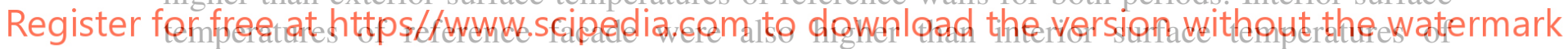

vegetated facade along the day time. Differences between maximum interior surface

temperatures of reference and vegetated facades were $1.3^{\circ} \mathrm{C}$ and $1.8^{\circ} \mathrm{C}$ for representative days in summer and fall periods, respectively (Fig. 3 and Fig. 4). Additionally, Fig. 3 presents that on August 12, indoor air temperatures behind both facades were not in the range of $23-26^{\circ} \mathrm{C}$ which is recommended as a comfort range for cooling period in ISO 7730:2005 Standard and ASHRAE Standard 55-2010. Nevertheless, on September 24, max. indoor air temperature $\left(25^{\circ} \mathrm{C}\right)$ behind vegetated facade is lower than upper limit value of $26^{\circ} \mathrm{C}$, while maximum indoor air temperature $\left(26.5^{\circ} \mathrm{C}\right)$ behind reference facade is higher than $26^{\circ} \mathrm{C}$ (Fig. 4).

\section{Discussion}

Although high differences between exterior surface temperatures of vegetated and reference walls were observed, there was no significant difference between interior surface temperatures of vegetated and reference walls. Also, there was no significant difference between indoor air temperatures behind vegetated and reference walls. The results regarding indoor air temperature differences between vegetated and reference facade showed similarities with the results of the study conducted under a different climate condition 
(Cfa:humid subtropical climates) by Chen et al., (2013) which revealed that cooling effect of VFS on the indoor environment is relative small because of the high heat resistance of the wall. If the existing exterior wall was designed without any thermal insulation, it is obvious that the VFS would present greater passive cooling effect. In addition, indoor air temperatures behind both rooms were not suitable according to comfort temperature ranges indicated in standards for representative summer day. Nevertheless, indoor air temperatures behind VFS were in the comfort range in the fall representative day in day time which required cooling, while indoor air temperatures behind reference facade were not in the comfort range. Also, it can be claimed that indoor air temperatures of both rooms were not only affected by exterior surface temperatures of south oriented walls, but also by the surface temperatures of interior walls, ceeling, slab and east oriented exterior walls. Also, it can be assumed that vegetated room gained and lost more heat through windows due to higher WWR compared with reference room. It can be claimed that if east facades of both rooms had same WWR, vegetated room would show greater performance in terms of indoor air temperatures compared with reference room.

\section{Conclusions}

It can be concluded that felt type VFS decreases exterior surface temperatures of an insulated existing wall located in Csa climate. In addition, most remarkable results were observed in fall period, and in that period the differences between exterior surface temperatures of

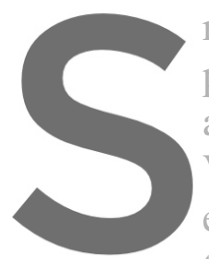
reference and vegetate positive contribution o addition, solar reflectan VFS. Although solar reflo exterior surface tempera
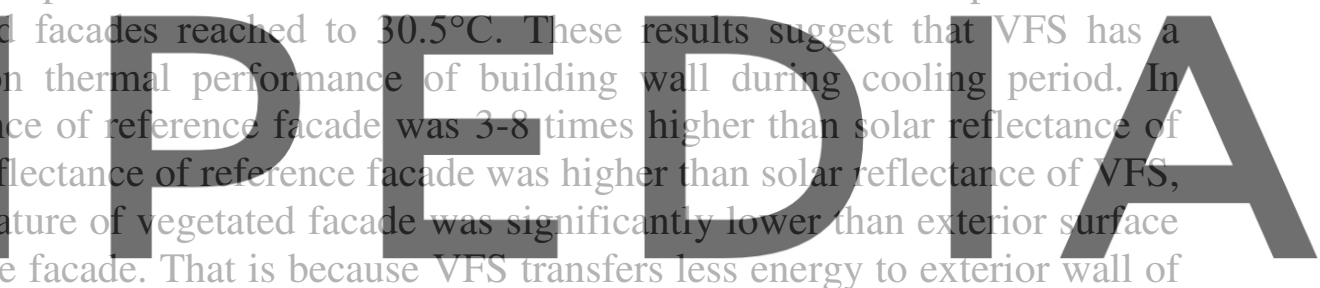
building even though VFS absorbs more solar radiation compared with reference facade

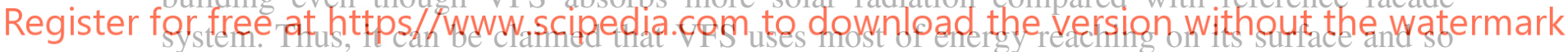
transfers less amount of energy to the exterior wall surface of building wall. Also, lower solar reflectance values of VFS indicate that these systems have positive impact on reducing urban heat island effect.

\section{Acknowledgements}

Authors gratefully acknowledge to Istanbul Technical University (ITU) Scientific Research Department for funding the research project.

\section{ORCID}

Elif Özer Yüksel: https://orcid.org/0000-0002-1041-8748

Nil Türkeri: https://orcid.org/0000-0003-4060-6528

\section{References}

Akbari, H., Kurn, D.M., Bretz, S.E. and Hanford, J.W. (1997). Peak Power and Cooling Energy Savings of Shade Trees. Energy and Buildings, 25, 139-148.

Alexandri, E. and Jones, P. (2008). Temperature Decreases inan Urban Canyon due to Green Walls and Green Roofs in Diverse Climates. Building and Environment, 43, 480-493. 
ASHRAE, ANSI/ASHRAE Standard 55-2010. Thermal environmental conditions for human occupancy, American Society of Heating, Ventilating and Air-conditioning Engineers. Atlanta, GA, USA.

ASTM E1918 (2006). Standard Test Method for Measuring Solar Reflectance of Horizontal and Low-Sloped Surfaces in the Field. ASTM International. USA.

Chen, Q., Li, B. and Liu, X. (2013). An experimental evaluation of the living wall system in hot and humid climate. Energy and Buildings, 61, 298-307.

Cheng, C.Y., Cheung, K.K.S. and Chu, L.M. (2010). Thermal Performance of a Vegetated Cladding System on Facade Walls. Building and Environment, 45, 1779-1787.

Feng, H. and Hewage, K. (2014). Energy Saving Performance of Green Vegetation on LEED Certified Building. Energy and Buildings, 75, 281-289.

GTU. (2017). http://wikimapia.org/15049881/tr/Gebze-Teknik-\%C3\%9Cniversitesi-GT\%C3\%9C\%C3\%87ay\%C4\%B1rova-Yerle\%C5\%9Fkesi (accessed 13 October 2017).

Haggag, M., Hassan, A. and Elmasry, S. (2014). Experimental Study on Reduced Heat Gain Through Green Facades in a Heat Load Climate. Energy and Buildings, 82, 668-674.

IPCC (Intergovernmental Panel on Climate Change). Working Group I: The Scientific Basis. (n.d.). http://www.ipcc.ch/ipccreports/tar/wg1/index.php?idp=5 (accessed 08.11.2017).

ISO 7730:2005. Ergonomics of the thermal environment-Analytical determination and interpretation of thermal comfort using calculation of the PMV and PPD indices and local thermal comfort criteria. International Organisation for Standardisation.

Kontoleon, K.J. and Eumorfopoulou, E.A. (2010). The Effect of the Orientation and Proportion of a PlantCovered Wall Layer on the Thermal Performance of a Building Zone. Building and Environment, 45, 12871303.

Koyama, T., Yoshinaga, M., Hayashi, H., Maeda, K. and Yamauchi A. (2013). Identification Of Key Plant Traits Contributing to the Cooling Effects of Green Façades Using Freestanding Walls. Building and Environment, 66, 96-103.

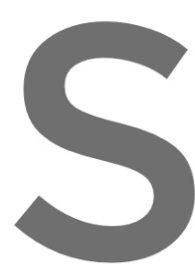

MCCAR (Massachusetts http://www.mass.gov

Olivieri, F., Olivieri, L. Insulated Vegetal Fac Environment, 77, 61-7

Perez, G., Coma, J., Sol, S
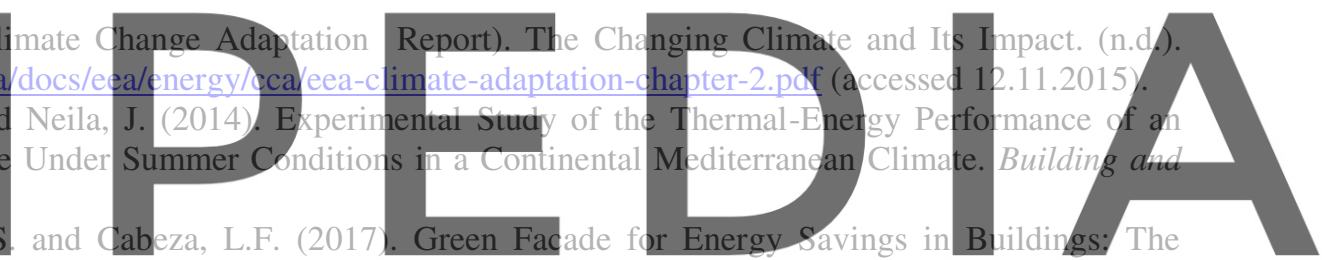
Influence of Leaf Area Index and Facade Orientation on the Shadow Effect. Applied Energy, 187, 424-437.

Perini, K., Ottele M., Fraai, A.L.A., Haas, E.M. and Raiteri, R. (2011). Vertical Greening Systems and the

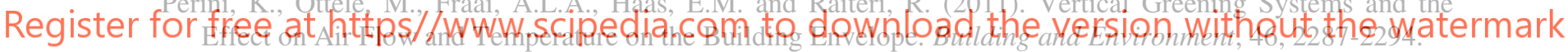

Raji, B., Tenpierik, M.J. and Dobbelsteen, A. (2015). The Impact of Greening Systems on Building Energy Performance: A Literature Review. Renewable and Sustainable Energy Reviews, 45, 610-623.

Safikhani, T., Abdullah, A.M., Ossen, D.R. and Baharvand, M.A. (2014). Review of Energy Characteristic of Vertical Greenery Systems. Renewable and Sustainable Energy Reviews, 40, 450-462.

Technology Roadmap, Energy Efficient Building Envelopes. (2013). https://www.iea.org/publications/freepublications/publication/TechnologyRoadmapEnergyEfficientBuilding Envelopes.pdf (accessed 01.11.2017).

Turkey's National Climate Change Adaptation Strategy. http://www.csb.gov.tr/db/iklim/editordosya/Adaptation_Strategy.pdf (accessed 20.07.2014).

Wong, N.H., Tan, A.Y.K., Chen, Y., Sekar, K., Tan, P. Y., Chan, D., Chiang, K. and Wong, N.C. (2010). Thermal Evaluation of Vertical Greenery Systems for Buildings Wall. Building and Environment, 45, 663672.

Yüksel, E. and Türkeri, A.N. (2016a). Sustainable Facade System: Types of Vegetated Facade Systems Designed and Constructed in Turkey, In Proceedings of SBE 16 Istanbul - International Conference on Sustainable Built Environment, 13-15 October 2016, Istanbul.

Yüksel, E. and Türkeri, A.N. (2016b). Bitkilendirilmiş Cephe Sistemlerinin Farklı İklim Bölgelerindeki Isıl Performanslarının Değerlendirilmesi, 2.Ulusal Yapı Fiziği ve Çevre Kontrolü Kongresi, 04-06 May 2016, Istanbul Technical University, İstanbul.

Yüksel, E. and Türkeri, A.N. (2017). Litterature Review of Experimental Setups Monitoring Thermal Performance of Vegetated Facade Systems, Journal of Facade Design \& Engineering, 5(2), 67-85. 